\title{
Atlantic Shortfin Mako: Chronicle of a Death Foretold?
}

\author{
Mercedes Rosello ${ }^{1, * \mathbb{D}}$, Juan Vilata ${ }^{2}$ and Dyhia Belhabib ${ }^{3}$ \\ 1 Leeds Law School, Leeds Beckett University, Leeds LS2 9TJ, UK \\ 2 Independent Researcher, 46014 Valencia, Spain; juanvilata@gmail.com \\ 3 Ecotrust Canada, 312 Main Street, Vancouver, BC V6A 2T2, Canada; dyhia@ecotrust.ca \\ * Correspondence: M.M.Rosello@leedsbeckett.ac.uk
}

check for

updates

Citation: Rosello, Mercedes, Juan Vilata, and Dyhia Belhabib. 2021.

Atlantic Shortfin Mako: Chronicle of a Death Foretold?. Laws 10: 52. https://doi.org/10.3390/ laws10030052

Received: 7 February 2021

Accepted: 15 June 2021

Published: 23 June 2021

Publisher's Note: MDPI stays neutral with regard to jurisdictional claims in published maps and institutional affiliations.

Copyright: (C) 2021 by the authors. Licensee MDPI, Basel, Switzerland. This article is an open access article distributed under the terms and conditions of the Creative Commons Attribution (CC BY) license (https:// creativecommons.org/licenses/by/ $4.0 /)$.

\begin{abstract}
This article outlines recent events concerning the conservation and management trajectory of a highly migratory shark species, the shortfin mako (Isurus oxyrinchus), in the North Atlantic, where it has been routinely captured recreationally and as part of commercial fishing operations alongside other species. Noting recent warnings concerning the high mortality of the species in this ocean region, and the threat of imminent population collapse, this article sets out a number of applicable law of the sea provisions, and carries out an evaluation of relevant measures for target and incidental capture species, discussing their applicability to the mako fishery. It also presents an analysis of regional and global governance actions taken to date by the international community and by individual actors, noting a number of shortfalls, and outlining potential responses.
\end{abstract}

Keywords: fisheries; bycatch; mako; UNCLOS; UNFSA; ICCAT; CITES

\section{Introduction}

Large pelagic megafauna has been targeted by a variety of commercial fishing fleets since the 1950s, with migratory pelagic sharks forming a significant part of both primary and incidental captures. Industrial longline fisheries in the Atlantic Ocean account for approximately $25 \%$ of global shark catches (Barreto et al. 2016). Large migratory sharks such as shortfin mako (Isurus oxyrinchus) are caught in particular by industrial pelagic longline vessels of different nationalities, both in the high seas and in the Exclusive Economic Zones (EEZs) of coastal States. Most North Atlantic shortfin mako captures are landed by the European Union (EU) fleet, with Spanish vessels recording the most landings, followed by vessels from Portugal (ICCAT 2018). Around 9\% of North Atlantic captures are attributed to vessels flagged to the United States (US) (ICCAT 2018; NOAA 2019). The North Atlantic shortfin mako is considered an incidental capture, or 'bycatch', carried out by vessels that are primarily targeting other commercial species. Although historically the primary targets of the longline fleets have been swordfish (Xiphias gladius) and tuna (Thunnus), shortfin mako is a common incidental capture. Being highly prized, it is regularly retained upon capture (Fernández-Costa et al. 2017; Coelho et al. 2017). In recent years, a decline in swordfish catches has been compensated by the adoption by some fleets of operational adaptations to opportunistically target pelagic sharks, ${ }^{1}$ for which there have been favourable market conditions ICCAT (2018).

The shortfin mako is a slow-growing species, and populations are particularly impacted by the fact that juvenile sharks are subject to high mortality and low post-release survival rates in fishing operations, thwarting recovery rates in fished populations (Byrne et al. 2017). Recent studies show that shortfin mako mortality in the North Atlantic ocean is likely to be high: the spatial distribution of this species shows a significant overlap with the longline fishing grounds, which increases its vulnerability (Queiroz et al. 2019). Moreover, tracking data from fisheries-independent studies 'raises questions about the true rate of fisheries

1 For swordfish capture trends, see http:/ / firms.fao.org/firms/resource/10023/en (accessed on 29 January 2021). 
mortality experienced by shortfin mako sharks, calling for a cautionary interpretation of past stock assessments used to determine management policy for this highly migratory species of conservation concern' (Vaudo et al. 2017).

The shortfin mako is amongst a number of migratory sharks that have recently been afforded international protection (CITES 2019). In 2019, the conference of the parties of the Convention on International Trade of Endangered Species (CITES) received a proposal to afford protection to this shark species. Proposals presented by Senegal and Canada referred to indications that the high mortality rate experienced by young and subadult mako sharks in the North Atlantic longline fisheries implied that, as older sharks die, their numbers cannot be replaced with younger specimens. According to the supplementary information presented to the CITES conference of the parties, the projections of population trends indicate that 'shortfin mako stocks are in danger of population collapse' (CITES 2019; Shark League 2019), and in respect of the North Atlantic population specifically it was indicated that 'CITES action in 2019 may be too late for the North Atlantic shortfin mako, but will be in time to prevent the commercial extinction of stocks in other oceans' (CITES 2019). Despite the gravity of these words, the proposal was met with resistance from the representatives of some CITES State parties, reflecting friction amongst delegates on the purpose of CITES, and its functional interactions with other international legal frameworks (Sellheim 2020). Such friction refers in particular to potential overlaps and tensions regarding existing cooperative arrangements established for the management of marine fisheries under the framework of the United Nations Convention on the Law of the Sea (UNCLOS). ${ }^{2}$ Concerns were raised regarding the appropriateness of the protections that had been afforded to the shortfin mako in the context of the regional decision-making fora usually known as regional fisheries management organisations (RFMOs) (CITES 2019). Amongst RFMOs, the International Commission for the Conservation of Atlantic Tunas (ICCAT), is the organisation entrusted with guiding the conservation and management of Atlantic tuna and tuna-like species such as swordfish. It also makes conservation recommendations in respect of Atlantic pelagic sharks, including shortfin mako. ${ }^{3}$

Against this backdrop, this article seeks to attain two interconnected objectives. Firstly, it seeks to examine the international legal protections established in UNCLOS and in its 1995 implementing treaty, the Fish Stocks Agreement (UNFSA) ${ }_{1}^{4}$ in respect of the conservation and management of the North Atlantic shortfin mako, and related cooperation obligations. Secondly, this article also seeks to evaluate the actions taken by the EU and the US in the context of subsequent ICCAT meeting of the contracting parties, ${ }^{5}$ in light of the obligations established in UNCLOS, and UNFSA. The actions under evaluation are presented in the context of the recommendations adopted by CITES, in view of the scientific information presented to both CITES and ICCAT, and by reference to specific provisions contained in international treaty and customary law. The focus on the US and the EU is justified not only due to the potential impact on the species derived from the positions adopted by the EU and the US during ICCAT proceedings in 2019, but also due to the vessels governed by the US and the EU being responsible for a significant proportion of captures in the North Atlantic fisheries in which shortfin mako is caught. The evaluation of their conduct against the above-mentioned legal texts is also accompanied by a brief enquiry into possible responsibility and reputational damage considerations in the context of the conservation and management obligations assumed by these actors.

The international obligations mentioned in this article are interpreted in accordance with the ordinary meaning of the words contained in each treaty provision, the fisheries context to which they pertain, and in light of the object and purpose of the treaties in

2 Convention on the Law of the Sea (1982) 1833 UNTS 397.

See www.iccat.int (accessed on 29 January 2021).

4 Agreement for the implementation of the Provisions of the United Nations Convention on the Law of the Sea of 10 December 1982 relating to the Conservation and Management of Straddling Fish Stocks and Highly Migratory Fish Stocks (1995) 2167 UNTS 3.

5 Curaçao joined the US in its proposal. See https://www.iccat.int/com2019/ENG/PA4_814_ENG_SPONS_1.pdf (accessed on 29 January 2021). 
question. ${ }^{6}$ The analysis of the international legal provisions is carried out in respect of three inter-connected areas. Firstly, the adoption of prescriptive measures for the conservation and management of the North Atlantic shortfin mako. Secondly, the relationship between cooperation and conservation and management of transboundary fisheries. Thirdly, the analysis also covers the duties of international actors in light of the classification of the North Atlantic shortfin mako as a bycatch species for fishery management purposes. Finding a number of potential shortfalls in respect of obligations found across these areas, the article concludes with a number of suggested options for the aforementioned actors.

\section{The Need for International Legal Protection}

During the CITES Conference of the Parties that took place in August 2019, States accepted the need to enhance international trade controls and oversight over shortfin mako and its products. The conference recommended their inclusion in CITES Appendix II, established to protect species that are not under immediate threat of extinction, but that require the adoption of controls over their entry into markets in order to prevent this fate. Species at risk of extinction are placed in Appendix I, an action that can severely restrict or suspend trade in the listed species and their parts and products (Favre 1989). Determining whether a particular species should be placed in Appendix I or II can be problematic. The proposals by Senegal and Canada noted that the shortfin mako is already threatened with extinction and the case for listing in Appendix II, as stipulated in the Convention text, is clear. Furthermore, in several locations the species meets the Appendix I criteria and requires full protection' (CITES 2019). Conference discussions concluded without a recommendation for the full protection for the species and resulted in the inclusion of the shortfin mako in CITES Appendix II. As a consequence, State parties have established import and export permits to ensure that any permitted trade is not detrimental to the species (Sellheim 2020), and placed restrictions on the international trade of mako and mako parts and products. ${ }^{7}$ In the EU, the Scientific Review Group on Trade in Wild Fauna and Flora has recommended the suspension of the import of specimens of North Atlantic shortfin mako under EU legislation concerning the protection of species of wild fauna and flora (SRGTWFF 2020).

The proposals presented during the CITES conference contained critical references to the management approach adopted under the auspices of RFMOs, specifically mentioning shortfin mako conservation and management as follows: 'Current fisheries management measures under ICCAT will not halt the decline', and, further: 'No other RFMOs limit mako catches, although the same intrinsic and extrinsic threats apply elsewhere' (CITES 2019). The international legal principles upon which RFMOs conduct their activities are set out in the UNCLOS and UNFSA, which contain the legal bases for cooperation in the conservation and management of marine fisheries, including highly migratory species like mako sharks. 8 The EU participates in and is bound to the obligations established in the UNCLOS to the extent permitted by its competences by virtue of UNCLOS Articles 305.1(f) to 307 and Annex IX. ${ }^{9}$ The US is not an UNCLOS party, but both the EU and US are parties to the UNFSA. ${ }^{10}$ Lastly, the UNFSA establishes the parameters for the adoption of conservation and management and other technical and compliance measures by RFMOs (Rayfuse 2015).

6 In accordance with Article 31.1 of the Vienna Convention on the Law of Treaties (1969) UNTS 1155, 331.

7 See, for example, international trade measures adopted by the Spanish Environment Agency Ministerio para la Transición Ecológica (Miteco), albeit not in coordination with capture permits. Available online: https://cepesca.es/el-sector-pesquero-exige-una-solucion-urgente-para-lacomercializacion-del-marrajo-dientuso-capturado-legalmente/ (accessed on 18 January 2021).

8 Highly migratory species are listed in UNCLOS Annex I.

9 See https:/ / ec.europa.eu/world/agreements / prepareCreateTreatiesWorkspace/treatiesGeneralData.do?step=0\&redirect=true\&treatyId=511 $($ ac cessed on 17 January 2021).

10 See https://www.un.org/Depts/los/reference_files/chronological_lists_of_ratifications.htm (accessed on 29 January 2021). 


\section{International Cooperation and Role of ICCAT}

Part V of UNCLOS contains several provisions that are relevant to the need for conservation for the purposes of managing straddling and highly migratory fisheries. In particular, Article 64(1) establishes the following: 'The coastal State and other States whose nationals fish in the region for the highly migratory species listed in Annex I shall cooperate directly or through appropriate international organizations with a view to ensuring conservation and promoting the objective of optimum utilization of such species throughout the region $(\ldots)^{\prime}$. This provision is relevant to highly migratory stocks occurring in marine areas within and without the EEZ. Beyond coastal State jurisdiction, UNCLOS also stipulates in its Article 118 that 'States shall cooperate with each other in the conservation and management of living resources in the areas of the high seas. States whose nationals exploit identical living resources, or different living resources in the same area, shall enter into negotiations with a view to taking the measures necessary for the conservation of the living resources concerned'. The duty to cooperate is thus closely linked to underlying considerations of conservation and management. This link is also made explicit in Article 117 of UNCLOS, whereby 'All States have the duty to take, or to cooperate with other States in taking, such measures for their respective nationals as may be necessary for the conservation of the living resources of the high seas'. Procedurally, the mentioned UNCLOS provisions establish an obligation that is appropriately discharged via negotiations in the cooperation forum provided by ICCAT, particularly as both the US and EU are contracting parties of this organisation. ${ }^{11}$ Substantively, the duty to cooperate does not imply any specific result. There are nevertheless due diligence expectations in respect of conduct that concern both procedure and substance: the negotiations should be undertaken meaningfully and with substantial effort, to ensure the adoption of appropriate and effective conservation and management measures. ${ }^{12}$

UNFSA has developed the cooperation framework for the conservation and management of straddling and highly migratory fisheries established in UNCLOS. The UNFSA regime is based on an organised regional approach that adds definition to the UNCLOS duties (Örebech et al. 1998). It consolidates the roles of RFMOs, which emerge as key authorities for the management of highly migratory and straddling species (OECD 2014). In particular, UNFSA Article 8(1) stipulates that States shall 'pursue cooperation in relation to straddling fish stocks and highly migratory fish stocks either directly or through appropriate subregional or regional fisheries management organizations or arrangements, taking into account the specific characteristics of the subregion or region, to ensure effective conservation and management of such stocks'. The specific emphasis on regional or subregional characteristics is important in the substantive context of the mako fishery, particularly in light of the situation of the species in the North Atlantic. Also important in this regard are UNFSA Articles 2 and 10, both of which highlight the long-term sustainability of straddling and highly migratory stock as a fundamental principle that underpins cooperation in matters covered by the UNFSA, including in respect of RFMOs functions.

Nevertheless, ICCAT predates this agreement (ICCAT 2019b), and a brief appraisal of its constitutive texts reveals a framework that lacks definition in substantive conservation matters, and a remit primarily focused on data collection and oversight over taxa. Annex I of the ICCAT Convention contains a provision in Article IV setting out the competences of the organisation over the study of tuna and tuna-like species, as well as 'such other species of fishes exploited in tuna fishing in the Convention area (...). Such study shall include research on the abundance, biometry and ecology of the fishes (...) and the effects of natural and human factors upon their abundance'. Article VI establishes the responsibility of ICCAT panels for 'keeping under review the species, group of species, or geographic area under its purview, and for collecting scientific and other information relating thereto'.

11 See https: / / www.iccat.int/en/contracting.html (accessed on 29 January 2021).

12 See Request for an Advisory Opinion Submitted by the Sub-Regional Fisheries Commission, Advisory Opinion [2015] ITLOS Reports 4, pp. 210-11 [SRFC]. See also Award in the Arbitration regarding the Chagos Marine Protected Area between Mauritius and the United Kingdom of Great Britain and Northern Ireland [2015] Reports of International Arbitral Awards, vol. XXXI, pp. 359-606, 530 and 535 [Chagos]. 
Available statistical, biological, and other scientific information is obtained by ICCAT via its contracting parties, as per Article IX, and can be disseminated via cooperative arrangements with the Food and Agriculture Organisation of the United Nations (FAO), including mutual assistance in fields of common interest (Franckx 2001).

Appropriate and accurate data collection is of the utmost importance for the successful management of a fishery. This is reflected in UNCLOS Article 119(2), whereby: 'Available scientific information, catch and fishing effort statistics, and other data relevant to the conservation of fish stocks shall be contributed and exchanged on a regular basis through competent international organizations, whether subregional, regional or global, where appropriate and with participation by all States concerned'. Article 119(2) clarifies the material content upon which the cooperation processes of Article 118 should be articulated, ensuring that decision-making takes place on the basis of available scientific understandings of the realities of the fishery. In addition, the UNFSA in Article 5(j) establishes the collection and sharing of comprehensive and accurate fishing activity data, including target and non-target species, as part of the general principles underpinning the agreement. The importance of information and oversight is further underlined in UNFSA Article 6(5) in respect of species whose conservation status is of concern. The UNFSA sets out data collection, reporting, verification, and data sharing duties, parameters, and standards in Articles 14, 18(e) to $(\mathrm{g})$, and Annex I. ${ }^{13}$

\section{ICCAT Proceedings}

In preparation for ICCAT discussions, the RFMO's committee concerned with conservation research and statistics produced a number of recommendations in 2019. With respect to the North Atlantic shortfin mako, they stated: 'Given the vulnerable biological characteristics of this stock and the pessimistic projections, to accelerate the rate of recovery and to increase the probability of success the Committee recommends that the Commission adopt a non-retention policy without exception in the North Atlantic as it has already done with other shark species caught as bycatch in ICCAT fisheries' (ICCAT 2019c). In light of this, the interventions of two specific contracting parties, the USA and the EU, merit attention. These are high profile international actors in matters concerning the management of transnational fisheries, who routinely perform a global policing role in matters of conservation, and of unregulated and illegal fishing control and compliance. Yet, in this case their interventions prevented the adoption of the measure proposed by the ICCAT research and statistics committee (ICCAT 2019d).

As a result, since 2019 has ICCAT produced little more for North Atlantic short mako sharks than a perpetuation of existing measures, which had already been proven to be insufficient, in view of prior CITES proceedings. Compulsory measures adopted by ICCAT are binding on contracting parties of the RFMO. ${ }^{14}$ Of course, States are free to unilaterally adopt stricter management measures for their own vessels, but the incentive to do so is undermined by two of the most significant actors in the fishery failing to adopt similar management standards. The measures that were eventually adopted require some consideration, particularly because they include live mako release (ICCAT 2019a). ${ }^{15}$ As previously noted, the post-release mortality of juvenile shortfin mako is thought to be significant (Byrne et al. 2017), capture can interrupt ram ventilation (Wegner et al. 2012), and injuries caused by hooking and handling can be severe (Campana et al. 2016) (Bowlby et al. 2020), among other factors. According to a study by Byrne et al. 'estimates of instantaneous fishing

13 The agreement sets out standard requirements for data collection and sharing in Annex I, and as an RFMO function in Article 10(e) of the same.

14 See Article VIII of the Beyond the International Convention for the Conservation of Atlantic Tunas (1966). ICCAT measures already described, EU vessels must also comply with any measures established in bilateral agreement regulating ICCAT fisheries occurring in coastal States where the EU fleet operates. For the purposes of the North Atlantic mako fishery, the EU and Cape Verde signed one such agreement, but no quota or other significant measure is adopted for mako sharks under this agreement. Essentially the mako is residually dealt with by the provisions established under the ICCAT framework.

15 Although the retention cannot be greater than average mako landings recorded by the flag state. Other measures were also adopted. Other measures included observer or camera equipment on board for vessels greater than 12 metres to assess if the shark was alive when brought on board, and permission to retain sharks over certain sizes on board when alive. There were also specific requirements for data collection including discards and releases. 
mortality rates $(. .$.$) were 10$-fold higher than previous estimates from fisheries-dependent data (...), suggesting data used in stock assessments may considerably underestimate fishing mortality' (Byrne et al. 2017). Hence, it is reasonable to argue that the non-retention advice of the research and statistics committee to ICCAT promotes a desirable policy of conscientious development, testing, and utilisation of selective fishing methods.

It is self-evident that a refusal by the US and the EU, as actors with significant stakes in the shortfin mako fishery, to enable the RFMO to adopt conservation measures as recommended by its own research and statistics committee has the potential to have considerable impact. This is likely not only on the species at risk, but also on the interests of other States whose vessels also participate in the fishery. In addition to this de facto management failure in the ICCAT discussions, efforts to understand the impacts of the long line fishery on shortfin mako had identified some areas of confusion in data collection, that could have resulted in catch underestimation (ICCAT 2017). The implementation of improved practices in catch data reporting was recommended alongside other measures in 2019, in order to support better decision-making in respect of the stock (ICCAT 2019e). Nevertheless, this comes too late for the North Atlantic shortfin mako, as knowledge gaps may well have contributed to the ongoing absence of effective measures, and the current poor state of the stock (Byrne et al. 2017).

\section{Conservation and Cooperation Duties under the UNCLOS Regime}

Disagreements amongst States are of course nothing new. In 1999, the International Tribunal for the Law of the Sea (ITLOS) was called on to take preliminary measures, aiming to secure the conservation and management of a specific bluefin tuna fishery that was at risk of depletion. This took place following disagreement by the parties involved in its capture as to the measures that were considered acceptable to prevent excessive deterioration of the stock. ${ }^{16}$ As in the present scenario, the Bluefin Tuna case concerned not only the impact of the fishery management decisions taken on an overexploited species, but also the need to respect the rights and interests of other States that also benefit from capturing the species in question. In this context, in its advisory opinion for the Sub Regional Fisheries Commission, ITLOS indicated that States have a right under Article 64(1) of the UNCLOS to require conservation related cooperation from other States in respect of straddling and highly migratory stock. ${ }^{17}$ These two deeply interconnected issues are reflected in UNFSA Article 8(2), whereby 'States shall enter into consultations in good faith and without delay, particularly where there is evidence that the straddling fish stocks and highly migratory fish stocks concerned may be under threat of over-exploitation', and further, '(...) Pending agreement on such arrangements, States shall observe the provisions of this Agreement and shall act in good faith and with due regard to the rights, interests and duties of other States'.

In addition to the above, the duty to cooperate also contains important substantive elements. In the high seas, UNCLOS Article 118 indicates the objective of cooperation to ensure conservation. Under Article 117 of UNCLOS, States are bound to cooperate with others in taking the measures that may be necessary for conservation in respect of the vessels they govern. As is clear from the combination of these provisions, the effort involved in the due diligence aspect of the duty to cooperate in the context of a transnational fishery concerns conservation considerations, which mere participation in a cooperation process cannot address by itself. Part XII of UNCLOS provisions are also applicable to the adoption of conservation and management measures for highly migratory species like the shortfin mako, as part of the broader protections afforded to the marine environment as a whole. Although most of the Part XII provisions implicitly or explicitly concern marine pollution, some are also relevant to the conservation of marine living

16 Southern Bluefin Tuna (New Zealand v. Japan; Australia v. Japan) (Provisional Measures), Order of 27 August 1999, ITLOS Reports (1999) 280 [Bluefin Tuna].

17 SRFC, para 218. 
resources. ${ }^{18}$ Specifically, UNCLOS Article 192 establishes an obligation to protect the marine environment in all ocean areas, ${ }^{19}$ and the scope of this obligation extends to the protection of fish stocks. In this regard, ITLOS has stated that the conservation of the living resources of the sea is an element in the protection and preservation of the marine environment', clarifying the broad spectrum of the duty, and the inclusion of a fisheries dimension. ${ }^{20}$ The adoption of protection measures can also be understood as a duty to refrain from enabling activities that cause damage to the marine environment and its habitats and species. ${ }^{21}$ This broad duty is a general obligation that predates UNCLOS, ${ }^{22}$ may form part of the corpus of international customary law (Roach 2014), and as such it is in principle binding on all States, including those that are not parties to the UNCLOS.

Vulnerable marine habitats and species are also protected by Article 194(5) of the UNCLOS. This provision establishes that special care must be taken including measures 'necessary to protect and preserve rare or fragile ecosystems as well as the habitat of depleted, threatened or endangered species and other forms of marine life'. The South China Sea award identifies CITES as an appropriate forum for interpreting instances of a species' vulnerability. ${ }^{23}$ The role that a pelagic predatory shark plays in its ecosystem and their components, such as trophic chains, is complex (Heupel et al. 2014; Lawton 1994), but the removal of a shark species can have impacts that transcend the species itself (Stevens et al. 2000), such as trophic chain disruption (Pauly and Palomares 2005), including impacts on the food webs that sustain other sharks (Kitchell et al. 2002). Hence, it is reasonable to assume that the duty established in UNCLOS Article 194(5) could in principle extend to actions that knowingly result in the collapse of a shark species, insofar as such removal has detrimental ecosystem effects.

The failure to attain an effective conservation outcome may not necessarily imply a breach of these duties, because as previously explained, they are not duties of result. They are instead duties in respect of which the actors must show that they have approached and engaged in proceedings with sufficient diligence. Nevertheless, States and other international actors with responsibility demonstrate diligence through the elaboration and adoption of conservation and management measures. These, as already discussed, can include measures to refrain from harvesting, particularly when the protection of vulnerable species is concerned. The content of the measures should be guided by suitably qualified scientists that are experts in their field, as determined by scientific enquiry (Tanaka 2020). Due diligence also requires States to invest effort in abiding by UNCLOS Article 119(1)(a) requiring States 'to maintain or restore populations of harvested species at levels which can produce the maximum sustainable yield' ${ }^{24}$ However, the provision contains a number of qualifications that States can take into account, such as economic considerations, which are explicitly enabled by 119(1)(a). Although the soft wording of this provision can accommodate State discretion (Takei 2013), any qualifications resulting in the abandonment of scientific recommendations concerning a species at risk of impending collapse, should be a last resort. Further, they should at least be proportionate with the anticipated risk on marine ecosystems and species (Venzke 2012), and on the rights and interests of other States. Qualifications would also need to be reasoned, ${ }^{25}$ and ideally be consistent with internal decisions. In the case of the EU, this would mean taking into

18 Bluefin Tuna, para 70. See also The South China Sea Arbitration (Republic of the Philippines v. People's Republic of China) (Award), 12 July 2016, PCA Award Series, 945 and 956 [South China Sea].

19 South China Sea, para 941 and 942.

20 South China Sea, para 70. See also SRFC, para 216.

21 South China Sea, para 944.

22 See Convention on the High Seas (1958) 450 UNTS 11. Also, Convention on Fishing and Conservation of the Living Resources of the High Seas (1958) 559 UNTS 285.

23 See South China Sea, para 956.

24 Reliance on Maximum Sustainable Yield is in itself controversial in the management of commercial fisheries. See, for example http://www. seaaroundus.org/fisheries-managers-should-not-abuse-maximum-sustainable-yield/ (accessed on 29 January 2021).

25 In respect of the need to provide reasons in the context of cooperation negotiations, see Chagos, para. 534. 
account the recommendation of its Scientific Review Group on Trade in Wild Fauna and Flora that, which implies a de facto recognition of stock crisis.

UNFSA recognises in Article 5(a) the principle of sustainability. The meaning of sustainable fishing was considered by the ITLOS, who understood it as a relevant principle for the conservation as well as the development of a fishery. Development was understood as follows: '(...) that these stocks should be used as fishery resources within the framework of a sustainable fisheries management regime. This may include (...) stock restoration, guided by the requirement under article 61 of the Convention that a given stock is not endangered by over-exploitation, thus preserving it as a long-term viable resource'. ${ }^{26}$ It is acknowledged that UNCLOS Article 61 concerns resources located in the EEZ. Nevertheless, conservation and sustainability are essential principles applicable also in the context of highly migratory species management. Further, in accordance with UNFSA Article 6, conservation and management measures need to incorporate a precautionary approach. Article 6 indicates that factors to take into account, which include 'inter alia, uncertainties relating to the size and productivity of the stocks, reference points, stock condition in relation to such reference points, levels and distribution of fishing mortality and the impact of fishing activities on non-target and associated or dependent species, as well as existing and predicted oceanic, environmental and socio-economic conditions'. It is difficult to reconcile the position of the EU and the US during ICCAT discussions with these precautionary provisions, in view of their status as UNFSA parties. Arguably, a precautionary approach also needs to be observed by virtue of being a contracting party to ICCAT, since it was adopted in a 2015 ICCAT resolution with respect to species under its oversight (ICCAT 2015).

\section{The Shortfin Mako as Incidental Capture Species}

The conservation of marine species that are captured incidentally is important, given that non-target species, whether they are utilised or discarded, are estimated to account for over $40 \%$ of global marine captures (Cassuto and O'Brien 2019). Bycatch species can sometimes be left unmanaged (Davies et al. 2009), although they can also at times be subject to management, as is the case for some species that are incidentally caught in fisheries overseen by ICCAT (Murua et al. 2013). Commercial fishing of tuna and tuna-like species does result in the incidental capture of sharks, ${ }^{27}$ and ICCAT has adopted a number of recommendations aimed at limiting fishing impacts on some shark species captured as bycatch (Davis et al. 2013). In a context where fishing activity typically results in captures of a mixture of species, the designation of a species as target, or as bycatch, non-target, or incidental capture is not inconsequential when it comes to international obligations.

In respect of target species, UNCLOS Article 119(1) requires State parties to determine the allowable catch and other conservation measures based on the best available scientific evidence, as previously explained. For incidental captures, Article 119 sets out a different approach, which does not include the establishment of total allowable catch: Article 119(1)(b) requires States to 'take into consideration the effects on species associated with or dependent upon harvested species with a view to maintaining or restoring populations (... ) above levels at which their reproduction may become seriously threatened'. In light of the scientific information available to ICCAT contracting parties and extensively discussed there and in the context of the CITES conference, it may be reasonably argued that the North Atlantic shortfin mako has become seriously threatened, and that restoring its population is now urgent. It is now also a precarious long-term project that may not be achieved unless the drastic non-retention measures advised by ICCAT's scientists are put into place. Yet, the soft conservation provision in UNCLOS Article 119(1)(b) may be seen as little more than a weak mechanism to safeguard opportunities to secure primary fishery target harvests, as much as the ultimate survival of the bycatch species.

6 SRFC, para 198.

27 However, some arts such as pole and line generate much lower impacts than pelagic long lines. 
It may, however, be questioned whether the lower protection threshold applicable to incidental capture species under Article 119(1)(b) is indeed appropriate for the North Atlantic shortfin mako, given that it is a commercial capture in its own right. It is also the case that the language of Articles 119(1)(a) and 64(1) is factual. Hence, 'harvested species' and 'whose nationals fish (...) for highly migratory species' could respectively be read to include species that, like the shortfin mako, and despite their bycatch status, are nevertheless retained on board for further utilisation and, thus, are in effect 'fished for' or 'harvested'. Indeed, when species retention in a mixed fishery is considered in light of changing market conditions and corresponding value to fishing actors over time, the rationale for persisting in considering increasingly sought-after species as incidental capture as a matter of operational economy can and should be questioned, particularly if this leads to an insufficient or inappropriate management approach.

Moreover, the UNFSA further defines the above obligations, and establishes a clear duty to adopt conservation and management measures for incidental capture species. In Article 5(d), the Agreement states that States shall 'adopt, where necessary, conservation and management measures for species belonging to the same ecosystem or associated with or dependent upon the target stocks, with a view to maintaining or restoring populations of such species above levels at which their reproduction may become seriously threatened'. Paragraph (f) of the same article also establishes a duty to minimize the catch of non-target species and impacts on associated species, particularly if they are endangered. Further, UNFSA exhorts parties to enhance selectivity in fishing methods wherever possible, and in paragraph (h) of Article 5 it calls for parties to prevent or eliminate overfishing, and to ensure that effort 'is commensurate with the sustainable use of the fishery'. This is further contextualised by Article 6 by reference to the precautionary approach, which explicitly includes species at risk by incidental capture, and which establishes a duty to apply the best available scientific knowledge, and stock-specific precautionary parameters for conservation and management, as further specified in Annex II of the agreement.

\section{Conclusions}

This article has offered an overview of the conservation and cooperation obligations established by the UNCLOS and the UNFSA in respect of the North Atlantic shortfin mako, and of the degree to which scientifically informed conservation and management measures are required for this species, given its status as incidental capture. Against the backdrop provided by the 18th CITES conference of the parties, this article has also assessed the actions of the US and the EU in the context of ICCAT proceedings, where the adoption of the non-retention measures advised by ICCAT scientists in 2019 was prevented.

Review of the protections afforded to straddling and highly migratory species by the UNCLOS has highlighted the close relationship between the obligation to cooperate, and duties established to ensure the conservation and management of living marine resources, as well as the safeguarding of the rights and interests of third States. The conservation and management obligations established in the UNCLOS in respect of straddling and migratory species permit considerable discretion in State decision-making, including qualifications of a non-scientific nature. However, such qualifications would need to take into account the likely damage to the environment and to the rights and interests of other States. It has also been highlighted that obligations established in UNCLOS Part XII to protect the marine environment, the natural resources it contains, and the ecosystems of vulnerable species concern ecosystem damage caused by human activity. The available evidence indicates that the removal of shark species from marine trophic chains can result in this type of damage. Additionally, UNCLOS obligations in respect of bycatch species have been analysed, and a rationale for restricting protections to a retained species like the shortfin mako to UNCLOS provisions dealing with incidental captures has been called into question. It has also been highlighted that bycatch species are protected under the UNFSA.

The authors conclude that the actions of the EU and US in the ICCAT forum are difficult to justify in light of the above analysis, particularly in view of the more defined 
conservation and precautionary duties established in the UNFSA. Moreover, as States have a right to require cooperation to ensure the long-term conservation of fisheries in which their vessels participate, it appears that those actions may not be wholly exempt from legal risk. To minimise such risk, and to address reputational damage, the EU and US should rectify their respective positions, so that alignment with existing scientific recommendations ensues. At the same time, conscientious development, testing, and utilisation of selective fishing methods should be prioritised.

Lastly, this article has also highlighted the existence of concerns over irregular data collection by ICCAT parties in recent years. This is problematic for the purposes of precautionary management, because inadequate data prevents and undermines the adoption of effective conservation provisions, falling short of some of the management duties discussed. Although ICCAT has reinforced its recommendations in this regard, care should be taken to ensure compliance and transparency in the resulting statistics. The case examined here should also prompt ICCAT parties to study appropriate conservation measures for mako sharks across the rest of the Atlantic, as populations are thought to be undergoing pressures similar to those of the North Atlantic shortfin mako (CITES 2019). It would also be appropriate for contracting parties to move without further delay towards effective conservation and management in respect of other incidental capture species currently unprotected across the ICCAT management area.

Author Contributions: Conceptualization, M.R., J.V., D.B.; methodology, M.R.; investigation, M.R., J.V., D.B.; original draft preparation, M.R.; review and editing, M.R., J.V., D.B. All authors have read and agreed to the published version of the manuscript.

Funding: This research received no external funding.

Institutional Review Board Statement: Not Applicable.

Informed Consent Statement: Not Applicable.

Conflicts of Interest: The authors declare no conflict of interest.

\section{References}

Barreto, Rodrigo R., Wialla K. T. de Farias, Humber Andrade, Francisco M. Santana, and Rosangela Lessa. 2016. Age, Growth and Spatial Distribution of the Life Stages of the Shortfin Mako, Isurus oxyrinchus (Rafinesque, 1810) Caught in the Western and Central Atlantic. PLoS ONE 11: e0153062. [CrossRef]

Bowlby, Heather, Warren Joyce, Hugues Benoit, and James Sulikowski. 2020. Evaluation of Post-Release Mortality for Porbeagle and Shortfin Mako Sharks from the Canadian Pelagic Longline Fishery. Collective Volumes of Scientific Papers 76: 365-73.

Byrne, Michael E., Enric Cortés, Jeremy J. Vaudo, Guy C. McN. Harvey, Mark Sampson, Bradley M. Wetherbee, and Mahmood Shivji. 2017. Satellite Telemetry Reveals Higher Fishing Mortality Rates than Previously Estimated, Suggesting Overfishing of an Apex Marine Predator. Proceedings of the Royal Society B 284: 20170658. [CrossRef] [PubMed]

Campana, Steven E., Warren Joyce, Mark Fowler, and Mark Showell. 2016. Discards, Hooking, and Post-Release Mortality of Porbeagle (Lamna Nasus), Shortfin Mako (Isurus Oxyrinchus), and Blue Shark (Prionace Glauca) in the Canadian Pelagic Longline Fishery. ICES Journal of Marine Science 73: 520-28. [CrossRef]

Cassuto, David N., and Amy M. O'Brien. 2019. You Don't Need Lungs to Suffer: Fish Suffering in the Age of Climate Change with a Call for Regulatory Reform. Canadian Journal of Comparative \& Contemporary Law 5: 31-76.

CITES. 2019. Supplementary Information on CITES COP 18 Proposal 42: Confirming that Shortfin and Longfin Mako Sharks fully Meet the Criteria for Inclusion on CITES Appendix II. Paper presented at Eighteenth Meeting of the Conference of the Parties, Geneva, Switzerland, June 17-28; CoP18 Inf. 40, 1 and 6. Available online: https://cites.org/sites/default/files/eng/cop/18 /inf/E-CoP18-Inf-040.pdf (accessed on 9 January 2021).

Coelho, R., A. Domingo, D. Courtney, E. Cortés, F. Arocha, K.-M. Liu, K. Yokawa, S. Yasuko, F. Hazin, D. Rosa, and et al. 2017. A Revision of the Shortfin Mako Shark Catch at Size in the Atlantic using Observer Data. ICCAT Collective Volumes of Scientific Papers 74: 1562-78.

Davies, R. W. D., S. J. Cripps, A. Nickson, and G. Porter. 2009. Defining and Estimating Global Marine fisheries Bycatch. Marine Policy 33: 661-72. [CrossRef]

Davis, Brendal, David L. Vander Zwaag, Aurelie Cosandey-Godin, Nigel E. Hussey, Steven T. Kessel, and Boris Worm. 2013. The Conservation of the Greenland Shark (Somniosus Microcephalus): Setting Scientific, Law, and Policy Coordinates for Avoiding a Species at Risk. Journal of International Wildlife Law and Policy 16: 300-30. [CrossRef]

Favre, David S. 1989. International Trade in Endangered Species: A Guide to CITES. Leiden: Martinus Nijhoff, p. 38. 
Fernández-Costa, José, Blanca García-Cortés, Ana Ramos-Cartelle, and Jaime Mejuto. 2017. Updated Standardized Catch Rates of Shortfin Mako (Isurus Oxyrinchus) Caught by the Spanish Surface Longline Fishery Targeting Swordfish in the Atlantic Ocean During the Period 1990-2015. Collective Volume of Scientific Papers ICCAT 74: 1730-45.

Franckx, Erik. 2001. Fisheries Enforcement Related Legal and Institutional Issues: National, Subregional or Regional Perspectives. Roma: FAO Legislative Study, p. 149.

Heupel, Michelle R., Danielle M. Knip, Colin A. Simpfendorfer, and Nicholas K. Dulvy. 2014. Sizing up the Ecological Role of Sharks as Predators. Marine Ecology Progress Series 495: 291-98. [CrossRef]

ICCAT. 2015. Resolution by ICCAT Concerning the Use of a Precautionary Approach in Implementing ICCAT Conservation and Management Measures. pp. 15-12. Available online: https://www.iccat.int/Documents /Recs/compendiopdf-e/2015-12-e.pdf (accessed on 9 January 2021).

ICCAT. 2017. Report of the 2017 ICCAT Shortfin Mako Assessment Meeting. Paper presented at International Commission for the Conservation of Atlantic Tunas, Madrid, Spain, June 12-16.

ICCAT. 2018. Report for Biennial Period 2018-19, Part I. pp. 231-32. Available online: https://www.iccat.int/Documents/BienRep/ REP_EN_18-19_I-2.pdf (accessed on 18 January 2021).

ICCAT. 2019a. 'Recommendation by ICCAT on the Conservation of North Atlantic Stock of Shortfin Mako Caught in Association with ICCAT Fisheries', 19-06. Available online: https://www.bmis-bycatch.org/regulations/recommendation-19-06 (accessed on 25 November 2019).

ICCAT. 2019b. Basic Texts, 7th Revision. Available online: https://www.iccat.int/Documents/Commission/BasicTexts.pdf (accessed on 17 January 2021).

ICCAT. 2019c. Report of the Standing Committee on Research and Statistics (SCRS). p. 230. Available online: https:/ / www.iccat.int/ Documents /Meetings/Docs/2019/REPORTS/2019_SCRS_ENG.pdf (accessed on 16 January 2021).

ICCAT. 2019d. Recommendation by ICCAT on the Conservation of North Atlantic Stock of Shortfin Mako Caught in Association with ICCAT Fisheries. Available online: https:/ /www.iccat.int/Documents/Recs/compendiopdf-e/2019-06-e.pdf; https:/ /biomeecology. com/marine-biology/2019/11/iccat-2019-mako-shark-protection-thwarted-by-eu-us/ (accessed on 29 January 2021).

ICCAT. 2019e. Report of the 2019 Shortfin Mako Shark Stock Assessment Update Meeting. Paper presented at Sma Shk Sa Intersessional Meeting, Madrid, Spain, May 20-24.

Kitchell, James F., Timothy E. Essington, Christofer H. Boggs, Daniel E. Schindler, and Carl J. Walters. 2002. The Role of Sharks and Longline Fisheries in a Pelagic Ecosystem of the Central Pacific. Ecosystems 5: 202-16. [CrossRef]

Lawton, John H. 1994. What Do Species Do in Ecosystems? Oikos 71: 367-74. [CrossRef]

Murua, Hilario, Francisco J. Abascal, J. Amande, P. Ariz, Pascal Bach, Pierre Chavance, R. Coelho, M. Korta, Francois Poisson, Bernard Seret, and et al. 2013. Provision of Scientific Advice for the Purpose of the Implementation of the EUPOA Sharks. European Commission Studies for Carrying out the Common Fisheries Policy. p. 66. Available online: https://ec.europa.eu/fisheries/ sites/fisheries/files/docs/body/scientific-advice-sharks_en.pdf (accessed on 29 January 2021).

NOAA. 2019. Atlantic Highly Migratory Species; Shortfin Mako Shark Management Measures; Final Amendment 11. US Federal Register 84: 5358, 5360. Available online: https:/ /www.federalregister.gov/documents/2019/02/21/2019-02946/atlantic-highlymigratory-species-shortfin-mako-shark-management-measures-final-amendment-11 (accessed on 3 March 2019).

OECD. 2014. Fishing for Development, Background Paper for Session 5: The Role of Regional Fisheries Management Organisations. TAD/FI(2014)11. Paris: OECD, p. 4.

Örebech, Peter, Ketill Sigurjonsson, and Ted L. McDorman. 1998. The 1995 United Nations Straddling and Highly Migratory Fish Stocks Agreement: Management, Enforcement and Dispute Settlement. International Journal of Marine and Coastal Law 13: 119-42. [CrossRef]

Pauly, Daniel, and Maria-Lourdes Palomares. 2005. Fishing Down Marine Food Webs: It Is Far More Pervasive than We Thought. Bulletin of Marine Science 76: 197-211.

Queiroz, Nuno, Nicolas E. Humphries, Ana Couto, Marisa Vedor, Ivo da Costa, Ana M. M. Sequeira, Gonzalo Mucientes, António M. Santos, Francisco J. Abascal, Debra L. Abercrombie, and et al. 2019. Global spatial risk assessment of sharks under the footprint of fisheries. Nature 572: 7770. [CrossRef] [PubMed]

Rayfuse, Rosemary. 2015. Regional Fisheries Management Organizations. In The Oxford Handbook of the Law of the Sea. Edited by Donald Rothwell, Alex G. Oude Elferink and Karen Nadine Scott. Oxford: Oxford University Press, p. 439.

Roach, J. Ashley. 2014. Today's Customary International Law of the Sea. Ocean Development E International Law 45: $239-59$.

Scientific Review Group on Trade in Wild Fauna and Flora (SRGTWFF). 2020. Short Summary of Conclusions (3 December 2020) 2. Available online: https:/ / ec.europa.eu/environment/cites/pdf/trade_regulations/short_ref_guide.pdf (accessed on 3 December 2020).

Sellheim, Nikolas. 2020. The CITES appendix II Listing of Mako Sharks: Revisiting Counter Arguments. Marine Policy 115: 103887. [CrossRef]

Shark League. 2019. Canada Joins Senegal to Champion Mako Shark Protection at International Fisheries Meeting. Available online: http:/ / www.sharkleague.org/2019/11/18/canada-joins-senegal-to-champion-mako-shark-protection-at-internationalfisheries-meeting/ (accessed on 9 January 2021).

Stevens, J. D., Ramón Bonfil, Nicholas K. Dulvy, and P. A. Walker. 2000. The Effects of Fishing on Sharks, Rays, and Chimaeras (Chondrichthyans), and the Implications for Marine Ecosystems. ICES Journal of Marine Science 57: 476-94. [CrossRef] 
Takei, Yoshinobu. 2013. Assessing Flag State Performance in Legal Terms: Clarifications of the Margin of Discretion. International Journal of Marine and Coastal Law 28: 97-133. [CrossRef]

Tanaka, Yoshifumi. 2020. Reflections on the Implications of Environmental Norms for Fishing: The Link between the Regulation of Fishing and the Protection of Marine Biological Diversity. International Community Law Review 22: 389-409. [CrossRef]

Vaudo, Jeremy J., Michael E. Byrne, Bradley M. Wetherbee, Guy M. Harvey, and Mahmood S. Shivji. 2017. Long-Term Satellite Tracking Reveals Region-Specific Movements of a Large Pelagic Predator, the Shortfin Mako Shark, in the Western North Atlantic Ocean Journal of Applied Ecology 54: 1765-75. [CrossRef]

Venzke, Ingo. 2012. Making General Exceptions: The Spell of Precedents in Developing Article XX GATT into Standards for Domestic Regulatory Policy. German Law Journal 12: 1111-40. [CrossRef]

Wegner, Nicholas C., N. Chin Lai, Kristina B. Bull, and Jeffrey B. Graham. 2012. Oxygen Utilization and the Branchial Pressure Gradient during Ram Ventilation of the Shortfin Mako, Isurus oxyrinchus: Is Lamnid Shark-Tuna Convergence Constrained by Elasmobranch Gill Morphology? Journal of Experimental Biology 215: 22-28. [CrossRef] [PubMed] 